\title{
Inclusive Education in East Java: The Case of Inclusive Education Policy and Practice in East Java, Indonesia
}

\author{
Ahsan Romadlon Junaidi \\ Departement of Special Education \\ Universitas Negeri Malang, Indonesia \\ aksan.romadlon.fip@um.ac.id
}

\begin{abstract}
Case study about inclusive education policy and practice in East Java in 2019 found some following problems: regulations of inclusive education have not been concurred to neither province nor regency governments; the education budget in regency is decreasing; the institution of inclusive education has not been spread in society; and there are not special education teachers in inclusive schools. Those problems correlate to the implementation of Act No. 23 of 2014 that said about the authority distribution in education management between both province and regency governments.
\end{abstract}

Keywords: inclusive education, policy

\section{INTRODUCTION}

The national legislations about inclusive education are found in Act No. 20 of 2003 about national education and Act No. 8 of 2014 about people with disabilities. Both regulations ensure that children with disabilities get education in regular or special schools. It means that based on the regulations, parents of children with disabilities are given authority to choose the school which are suitable for their children.

In East Java province, the implementation of inclusive education was begun in 2007. The policy about exertion of inclusive education as first design of East Java Governor's Adjustment was in 2011. The implementation of inclusive education in East Java faces some problems. According to preface study in 2013, it found the following problems: (1) around $67 \%$ of regency government had not have regulation about inclusive education yet; (2) then, $28 \%$ of regency government had not have budget plan related to the development of inclusive education yet; (3) all governments in regency had not have data of children with disabilities who had not gotten education service; (4) the school existence as the caretaker inclusive education has not been spread evenly in each district for basic education (elementary and secondary school); (5) the 64,7\% of area have problems about the school legality as the executor of inclusive education, because they have not gotten appointment letter from government (Junaidi, 2015).

Along with the policy change about the management authority of education between province and regency governments referring to Act No. 23 of 2014 about regency reign, it needs to know how far the inclusive education policy and implementation in East Java. The Act No. 23 of 2014 was applied in east Java Province started from the beginning of 2017. The whole inclusive education problems based on the above study in 2013 became the reason to do research to know the development of inclusive education implementation in East Java.

\section{THEORETICAL FRAMEWORK}

The inclusive education practice is influenced by legislation and policy, then legislation and policy are influenced by the stakeholders' principles and personal belief (Dempsey, 2011). Some principles that become inclusive education foundation are tenet about social justice and human right. This tenet teaches that everyone without any considering the diverse of gender, religion, ethnicity, race and disability, has the same right to get quality education which close to his/her residence (Foreman, 2014).

The controversy of education service for children with disabilities influences the principle and belief that determine legislations and policies about inclusive education. For the supporter of inclusive education proposes opinion that inclusive education implementation can increase accessibility of education service for marginal group, including children with disabilities. In contrast, the opponent of inclusive education will criticize the less of resources in regular school for children with disabilities that impact to unsuitable service (Brodin \& Lindstrand, 2007).

In Sweden, it had been discussed since 1950 about the policy concept to take people with disabilities in social environment, so that they would not be discriminated anymore in special institutions such as dormitory and special school. This principle was well known integration and normalization concept (Bines, 2000). Bines in his study about policy of special education needs in England and Wales created three categories; the traditional system of special education provision, government-led reform of school management and curricula, and professionally-led redefinitions of good practice in relation to roles and provision (Bines, 2000).

In doing collaborative action research in school systems in some countries like Australia, Brazil, England, Romania, Portugal, Spain, and Zambia, Ainscow and Miles gave pressuring about the importance of inclusive education definition that can be known clearly by the stakeholders (Ainscow \& Miles, 2014). Moreover, Ainscow and Miles developed framework in developing education system inclusively, like what the following picture said (Ainscow \& Miles, 2014). 
Based on the framework in the Figure 1 above, it can be assumed that development process of inclusive education system was done dynamically and continuously. Conceptual comprehension about inclusive education must be clearly based on the principles and philosophy of inclusive education. The comprehension has impact to legislation and policy about inclusive education. Likewise, the inclusive education legislation and policy determine the development of structure, system, and the implementation or practice of inclusive education. This framework is used as lens to see inclusive education in East Java Province (Figure 1).

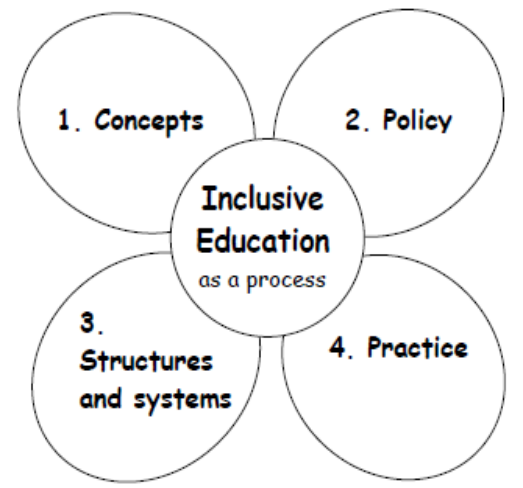

Figure 1

Framework of Developing Education System

\section{METHODS}

This research uses qualitative research approach. Case study is chosen as the research strategy and the analysis unit in this research is the government of East Java Province. The methods of data collection are: (1) the documentation about policy and publication of inclusive education by the government of East Java Province; (2) Group interviewing in Focus Group Discussion (FGD), and supported by unstructured interviewing with the key informant in education official of East Java province, education official of Lumajang Regency, Pasuruan City, Ngawi Regency, and Tulungagung Regency.

\section{RESULTS}

Several problems in inclusive education practice in East Java are presented below.

\section{A. The Regulation of Inclusive Education}

The problems of inclusive education regulation appear along with the implementation of Act No. 23 of 2014 about Regency Reign. In this Act is not explicitly regulating about management authority of inclusive education. According to Act No. 23 of 2014, the authority of province government is to manage secondary education and special education. Otherwise, the regency government has authority to manage early childhood education, nonformal education and basic education.

Therefore, in province level of East java, the regulation about inclusive education is arranged in ordinance of both regency and governor. The regulation of East Java Province No. 17 of 2017 about the education executor regulates the implementation of inclusive education generally and operationally arranged in governor ordinance No. 30 of 2018 which is about the implementation of inclusive education. Referring to Governor Ordinance No. 30 of 2018, it can be assumed that inclusive education management operates based on the authority of education management which was stated in Act No. 23 of 2014. By this understanding, the Province Government has responsibility to inclusive education management for secondary education level; senior general secondary schools, that is Sekolah Menengah Atas (SMA) and vocational secondary schools, that is Sekolah Menengah Kejuruan (SMK). The Regency government operates inclusive education in childhood education and basic education level that are kindergarten, elementary, and junior high schools.

The regulation problems about inclusive education management after the realization Act No 23 of 2014 has not been followed by the concord and changed the regulation in Regency level. So, the problems appear are not only around $48 \%$ of Regency/City in East Java that have no regulation about inclusive education, while it is about $90 \%$ area has not had the same regulation in Regency level in case of inclusive education management problems with the regulation in province.

\section{B. The Budget Plan of Inclusive Education}

The budget plan problems for developing inclusive education from Regency shows decreasing to compare from the data in 2013. It is based on the number of regencies and allocation. Along with the implementation of Act no. 23 of 2014, some regencies stop giving budget for developing inclusive education by the reason that inclusive education is part of special education and it becomes the province government's authority. Some regencies reduced budget allocation because senior general secondary school and vocational secondary school becomes the Province Government's authority. In contrast, the budget plan in Province Government of East Java is increasing. Generally, the budget allocation of inclusive education development by East Java Government is used for developing teachers' competence through workshop and training, upgrading of understanding about inclusive education can be from publication and campaign awareness, and is also used as incentive for special education teacher, that is Guru Pembimbing Khusus (GPK).

\section{The Data of Children with Disability}

The problems of data availability of children with disability who have not gotten education service still become set of problems in both province and regency governments in East Java. The available data are children with disability who have gotten education service in the institution of special education (TKLB, SDLB, SMPLB, SMALB) and in the institution of regular education (SD, SMP, SMA, and SMK). In 2017, the data of children with disability in East Java which have not gotten education service yet were predicted around $55,3 \%$, this data was from referring to population data of children with disability from Social Agency of East Java Province (E. Purbaningrum, A. Kurniawan, 2017).

The data of children with disability which have gotten education service in the caretaker of inclusive education in 2017 is based on the data that were modified from Education Main Data of Ministry of Education that is Data Pokok Pendidikan (Dapodik) can be seen from following diagram. According to data of disability students that 
published from Dapodik in 2017 in East Java thoroughly are 4.532 students. From the data, the most pupils with disability are from elementary school which is 3.239 students. From this pole diagram, it shows that the spreading of disability students in TK, SD, SMP, SMA, and SMK (Figure 2).

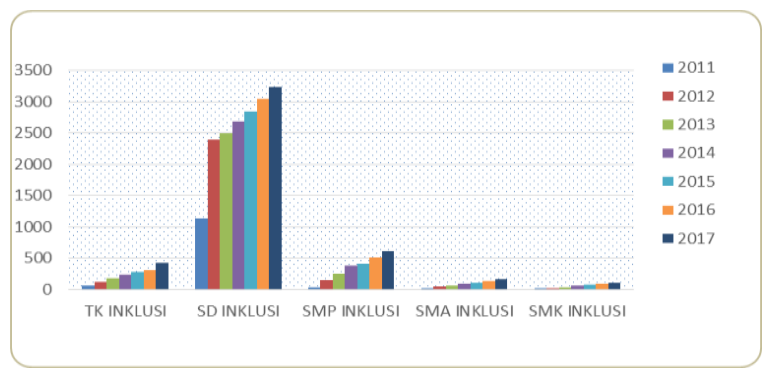

Figure 2

The Spreading of Students with Disability in East Java

\section{The Data of Inclusive Education Schools}

The inclusive education development in East Java has not spread yet through the whole regencies. From figure 3 below, it is showed that the number of inclusive education schools from elementary to secondary that are SD, SMP, SMA, and SMK in 2017 through regencies in East Java.

The data referred to Dapodik which was downloaded in 2017. The weakness from this data is strongly depending on the school awareness to input the data of students with disability in Dapodik system. From triangulation data, it is known that there was a school in 2017 actually had students with disability; otherwise they were not input in Dapodik. Most school that did not input the data of students with disability said that they did not know the feature to input data about special needs which was served in Dapodik system (Figure 3).

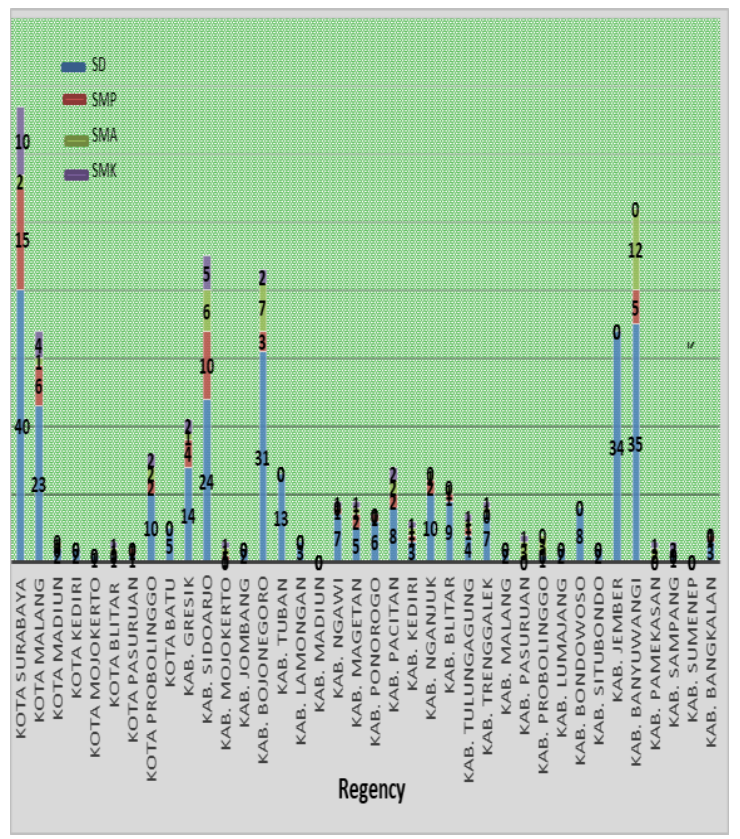

Figure 3

The Spreading of Inclusive Education Schools 2017 in East Java

Along with the implementation of Act No. 23 of 2014 about Regency Reign, Province Government of East Java keeps staying to develop inclusive education by adding the number of education institution as the executor of inclusive education in secondary education level. The following table describes the development of the inclusive education number in general secondary schools and vocational secondary schools that is appointed to hold inclusive education through the judgment letter from the chief of Education Official.

Table 1

The development of the Education Institution Number

\begin{tabular}{|c|c|c|c|}
\hline $\begin{array}{c}\text { Academic } \\
\text { Years }\end{array}$ & $\begin{array}{c}\text { Spreading of 38 } \\
\text { Regency }\end{array}$ & $\begin{array}{c}\text { State } \\
\text { Schools }\end{array}$ & $\begin{array}{c}\text { Private } \\
\text { Schools }\end{array}$ \\
\hline $2017 / 2018$ & 12 & 88 & - \\
\hline $2018 / 2019$ & 25 & 110 & 12 \\
\hline $2019 / 2020$ & 30 & 138 & 12 \\
\hline
\end{tabular}

\section{E. The Legality of Inclusive Education Schools}

The legality of education institution as the caretaker of inclusive education here relates to the education institution fulfillment as the inclusive caretaker. This fulfillment belongs to the regency's authority. It means that the fulfillment at basic education level (elementary school and junior secondary school) is done by regent or the chief of Education Official. For the secondary education level (general secondary schools and vocational secondary schools), the fulfillment belongs to Governor or the chief of Province Education Official.

The legality problem of this inclusive education caretaker has two crucial focuses. The first refers to inputting process in Dapodik system. In Dapodik application, there is a feature for education institution which is submitting the data of students with disability to input information data about judgment letter relating to an appointment education institution as the inclusive education caretaker. The second refers to system of accepting new students that is Penerimaan Peserta Didik Baru (PPDB). In PPDB system of state education institution, government needs to make sure that the certain institutions become the caretaker of inclusive education and then people know well the information about it.

In this basic education level (elementary school and junior secondary school), from 38 regencies there are still some regencies which get misunderstanding about the judgment letter. It is because they have not understood yet that inclusive education in basic level belongs to regencies' authority. Some of them think that inclusive education is same as special education which becomes province government's authority.

In the secondary education level (general secondary schools and vocational secondary schools), which belongs to province government's authority has no problem related to legality. This can be seen from table 1, which presents the development of inclusive education schools' number. Even though for this, some of them said that the inclusive school can be started by having students with special need. Then, it will be supported also by the letter from government.

\section{F. Special Education Teacher}

The existence of special education teacher in an education institution as the inclusive education caretaker becomes interesting theme to discuss from the view of policy and the implementation. Referring to government regulation No. 17 of 2010 about managing and organizing 
education, special education teacher is categorized as the professional educator such as teacher, lecturer, counselor, advisor, and etc. (article 171). As a professional educator, special education teacher has jobs to guide, teach, assess, and evaluate students with special need in general, specific, and/or religious education institution (article 171 , verse 2 , letter $\mathrm{j}$ ). Special education teacher concepts are covered by regulation No. 17 of 2010 means that as a professional educator, the qualification of special education teacher must be the degree of special education.

The special education teacher concepts are stated in regulation No. 17 of 2010, it is different from regulation No. 19 of 2017 which is about the change for regulation No. 74 of 2008 about teacher. In regulation No. 19 of 2017, special education teacher is given additional task for them which is still relating to the right to get financial aid for teacher (article 15, verse 2). The additional job is like other additional job, such as vice of chief in education institution, library chairman, and chief of laboratory. On the other hand, special education teacher does not mean as an educator who "must" have the degree of special education qualification.

For the implementation, the existence of special education teacher is interesting to know. In the education institution as the inclusive education caretaker, the existence of special education teacher has two characteristics. First, special education teacher is a professional teacher that have to guide, teach, assess, and evaluate students with disability, it is not as additional job. The academic qualification should be the degree of special education, psychology, guiding and counseling, and the other educational degree. The more interesting is there were 32 recruitment special education teachers with special education qualification in Pasuruan City in state employee accepting, but they were sent as teacher in elementary school and junior high school.

Secondly, special education teacher who are sent as additional task with 6 hours equivalence in a week. This concept is mostly adopted by many schools in East Java. Therefore, to prepare special education's job as additional task, they have to join workshop, training, and other professional development program in case of improving teachers' competence as special education teacher. Referring to this concept, province government of East Java asked special education teacher as additional job in each state general secondary schools and vocational secondary schools (SMA and SMK); as the inclusive education caretaker.

\section{DISCUSSION}

The one of inclusive education policy and implementation problems in East Java is caused by the various understandings of inclusive education, policy, and the implementation among the stakeholders. The inclusive education misunderstanding occurs also in other countries. In New Zealand, many teachers and principals have the same misunderstanding to understand inclusive education concept and the implementation in school (Hornby, 2012).

The problems of understanding, policy and inclusive education implementation occurred also in United State in the beginning of inclusive education implementation. Based on Stevens, Everington, and Stacy teachers assumed that "mainstreaming" concept was known that students who were able to join in regular program could participate the curriculum as well as other students in the regular program class (Thomazet, 2009). So, the problems which appeared in the implementation of inclusive education in East Java were natural dynamics in which other countries also faced them in developing inclusive education.

The problems of authority distribution between Central Government and Local Government that have impacts to some problems in inclusive education regulation, policy, and implementation were also happened in Finland. According to Ketovuori, in general, national policy and regulation in Finland support inclusive education, but the autonomy in local government level has impacts to the varied of inclusive education implementation in region. There was a region that its implementation of education was very inclusive, on the other sides; there was region with the segregated implementation (Halinen \& Järvinen, 2008). The tendencies in Finland were the increasing of pupil's total with special needs in regular school, while it increased also the number of pupils with special needs in special school. These cases were predicted because - occurred also in many countries - the education policy gave freedom for parents to choose school for their children with special needs (Kivirauma, Klemelä, \& Rinne, 2006).

The policy to give education service for students with special needs in two system choices - special and regular school - were well known as dual system (Ferguson, 1998). This dual system can be integrated into an education system inclusively. Ferguson did collaborative research in three districts in Oregon for three years, it showed that a principle and teachers in the regular school gradually restructured in giving support to students with disabilities fundamentally. As the result, students with disabilities were fully included in the learning life of the school community. Referring to the data in 1995, there were $72 \%$ students with disabilities in Oregon accepted in public school ((UIS), 2018).

The problems of budget decreasing for inclusive education development in regency/city in East Java, besides relating to comprehension problem about the authority of education management, it was also caused by no data of children with disabilities who had not got education service yet. Referring to UNESCO's data in 2006, it said that more that $90 \%$ children with disabilities in developing countries had not got the education service (Dempsey, 2011). The existence of children with disabilities data that had not obtained the education service yet in each regency could become crucial indicators of the accessibility problem in education service, that's why it needs to be the priority program, including in budgeting.

The data existence of the number of students with disabilities in inclusive school, besides it is used as indicator of students with disabilities participation level in obtaining education service, it can be also used for counting foundation of budgeting needs in inclusive education development. The data of analysis result that was done by UNESCO in 2018 showed that Indonesia had participations with disabilities in $15-29$ ages which had ever joined school around 52,5\% ((UIS), 2018). The 
problem todays is about the counting of budgeting unit for every child with disabilities is not clear between the service of special and inclusive school. In New Zealand, there is also same budgeting problem related to budgeting style and the counting of budgeting unit in inclusive education implementation (Hornby, 2012).

As a reference on counting budgeting needs of inclusive education, referring to workshop result in International Conference of education (ICE) in Genewa 2008 (Opertti \& Belalcázar, 2008), which involves the representatives of Eastern and South-Eastern Europe countries, as well as the Commonwealth of Independent States (CIS) and most parts of Asia. The funding in inclusive education development was used for: (a) preservice and in-service teacher education programmers; (b) advocacy to increase social awareness; (c) school facilities; (d) teaching materials; and (e) special classroom support.

The existence of special education teachers in inclusive school are needed relating to the service for students with disabilities. Cooperation between special education and regular teachers become important part in learning management in the class. The integration of professional cooperation between regular and professional teachers in organizing class and learning process so that the various needs of students in inclusive class can be served well, becomes the success key of inclusive education practice (Ferguson, 1998).

Relating to professional teachers' existence with special education degree qualification in inclusive schools, New Zealand has the same problems. Referring to Wylie's reports (Hornby, 2012) said that education ministry had not applied the Special Needs Education, Needs Coordinators. A new school instructed staffs to hold the task, in real fact they did not have enough time and skill in the special education.

The implementation of inclusive education with the various students in a class, demand the teacher's competence in a regular school in order to manage the class and apply the learning by considering the diversity of students. Yustake and learner's research concluded that regular or public-school teacher felt to have inadequate practical training to result successful inclusion. They also thought that the support from special educational teachers to regular teachers was considered inadequately (Dingle, Falvey, Givner, \& Haager, 2004). Another research which was done by Wigle and Wilcox recommended both special education and regular teachers had knowledge and skill to collaborate and cooperate effectively. Both teachers must also have skill to modify education program in order to be affective in meeting individual needs of students with disability (Dingle et al., 2004).

Olson, Chalmer and Hoover (Dingle et al., 2004) did interview deeply to teachers in regular school which was experienced in serving students with disability in inclusive class set, recommended some ideal descriptions which must be covered by regular teacher, they are ; (1) having tolerance, reflective, and flexible; (2) responsible to all students, including students with disabilities; (3) be able to cooperate with special education teacher; (4) be able to create climate and culture of friendly class; (5) be able to be model or figure in accepting and cooperating with people with disabilities.
Therefore, it can be concluded that inclusive education implementation needs teachers with special education degree qualification and regular teachers have competence like what Olson, Chalmers and Hoover described above. Workshop and training that were held by Government of East Java Province and local government to regular teacher can be assumed as steps to improve their competence in diversity class managements. According to Barton, the term 'diversity' signifies both the identification and celebration of difference, within structures and processes that are available to all learners (Moran, 2009).

\section{CONCLUSION}

According to the data explanation in above research finding, it can be assumed that after the implementation of Act No. 23 of 2014 about regency reign, there were impacts to inclusive education policy and implementation in East Java. The distribution of government's authority between province and regency correlated to inclusive education that had not been known well by the stakeholders. It has impacts to the less concord to the regulation in both province and regency level. This regulation problem will be ensued to budget allocation in regency government to the inclusive education development. Then, it correlates also to the legality problem; appointment or fulfilment to education unit as the inclusive education executor in basic education level (elementary school, and junior high school).

On the other sides, after the implementation of Act No. 23 of 2014, province government responded to regency's and Governor's regulation which are relating to inclusive education. Beside the regulation problem, province government of East Java develops inclusive education in general secondary schools and vocational secondary schools (SMA and SMK) level and gives budgeting for increasing teachers' competence and incentive for special education teachers. The existence of special education teachers in inclusive school need to be emphasized by the qualification of special education degree. Improvement of regular teachers' competence is also needed in order they can run the inclusive education very well.

The distribution of authority in managing education between province and regency governments needs to have coordination and corporation each other. It's really needed to do to make sure the continuance of inclusive education implementation from basic education level (SD and SMP) to secondary education level (SMA and SMK).

\section{REFERENCES}

[1] (UIS), U. I. for S. (2018). Education and disability: analysis of data from 49 countries.

[2] Ainscow, M., \& Miles, S. (2014). Developing inclusive education systems: How can we move policies forward? Chapter prepared for a book in Spanish to be edited by Climent Gine et al.

[3] Bines, H. (2000). Inclusive standards? Current developments in policy for special educational needs in England and Wales. Oxford Review of Education, 26(1), 21-33.

[4] Brodin, J., \& Lindstrand, P. (2007). Perspectives of a school for all. International Journal of Inclusive Education, 11(2), 133-145. 
[5] Dempsey, I. (2011). Legislation, policies and inclusive practices.

[6] Dingle, M., Falvey, M. A., Givner, C. C., \& Haager, D. (2004). Essential Special and General Education Teacher Competencies for Preparing Teachers for Inclusive Settings. Issues in Teacher Education, 13(1), 35-50.

[7] E. Purbaningrum, A. Kurniawan, F. M. (2017). Profil Anak Berkebutuhan Khusus (ABK) Provinsi Jawa Timur. Surabaya.

[8] Ferguson, D. L. (1998). Changing tactics: Embedding inclusion reforms within general education restructuring efforts. International Journal of Educational Research, 29(2), 143-159.

[9] Foreman, P. (2014). Inclusion in action. Cengage Learning Australia.

[10] Halinen, I., \& Järvinen, R. (2008). Towards inclusive education: the case of Finland. Prospects, 38(1), 77-97.

[11] Hornby, G. (2012). Inclusive education for children with special education needs: A critique of policy and practice in New Zealand. Journal of International and Comparative Education (JICE), 52-60.

[12] Junaidi, A. R. (2015). Profil Pendidikan Inklusif di Jawa
Timur Tahun 2013. Seminar Nasional Pendidikan Khusus Pengembangan Pendidikan Bagi Anak Berkebutuhan Khusus Menghadapi Globalisasi Pendidikan Abad 21, Diselenggarakan Oleh Program Studi Pendidikan Luar Biasa FKIP Universitas Lambung Mangkurat Bekerjasama Dengan Asosiasi Pro, 40-46. Banjarmasin.

[13] Kivirauma, J., Klemelä, K., \& Rinne, R. (2006) Segregation, integration, inclusion-the ideology and reality in Finland. European Journal of Special Needs Education, 21(2), 117-133.

[14] Moran, A. (2009). Can a competence or standards model facilitate an inclusive approach to teacher education? International Journal of Inclusive Education, 13(1), 4561

[15] Opertti, R., \& Belalcázar, C. (2008). Trends in inclusive education at regional and interregional levels: issues and challenges. Prospects, 38(1), 113-135.

[16] Thomazet, S. (2009). From integration to inclusive education: Does changing the terms improve practice? International Journal of Inclusive Education, 13(6), 553563. 